\title{
PENATAAN DAN PELESTARIAN KAWASAN BERSEJARAH KOTA SAWAHLUNTO SEBAGAI KOTA PUSAKA INDONESIA
}

\author{
Fery Mulya Pratama ${ }^{1}$, Nia Suryani ${ }^{2}$ \\ ${ }^{1}$ Universitas Indraprasta PGRI, Program Studi Arsitektur \\ pratama.ars@gmail.com \\ ${ }^{2}$ Universitas Indraprasta PGRI, Program Studi Arsitektur \\ niasuwardi@gmail.com
}

\begin{abstract}
Sawahlunto City in West Sumatra Province is one of the cities incorporated in the Jaringan Kota Pusaka Indonesia (JKPI) dalam P3KP (Program Penataan dan Pelestarian Kota Pusaka) aims to maintain heritage assets. The heritage assets of Sawahlunto City are inseparable from the history and glory of this city in the past, especially during the Dutch colonial period. This research aims to identify the variety of heirlooms and formulate a conservation strategy for Sawahlunto Heritage City. The method used is descriptive qualitative and exploratory study of history, culture and policy. Data were collected by field surveys, literature studies and interviews. The result of the research is that the structure of Sawahlunto City is developed based on the potential of the inheritance assets owned so that the city can survive, live, and be sustainable with the concept of living museum applied to the Priority Area of Kawasan Kota Lama.
\end{abstract}

Keywords: heritage city, living museum, priority area

\begin{abstract}
Abstrak : Kota Sawahlunto di Provinsi Sumatera Barat merupakan salah satu kota yang tergabung dalam Jaringan Kota Pusaka Indonesia (JKPI) dalam P3KP (Program Penataan dan Pelestarian Kota Pusaka) bertujuan untuk mempertahankan aset pusaka. Aset pusaka Kota Sawahlunto tidak terlepas dari sejarah dan kejayaan kota ini pada masa lalu khususnya pada masa penjajahan Belanda. Penelitian ini bertujuan mengidentifikasi ragam pusaka dan merumuskan strategi pelestarian Kota Pusaka Sawahlunto. Metode yang digunakan adalah kualitatif deskriptif dan ekslporatif dengan kajian sejarah, budaya dan kebijakan. Data dikumpulkan dengan survei lapangan, studi literatur dan wawancara. Hasil penelitian diperoleh struktur Kota Sawahlunto dikembangkan berdasarkan potensi aset pusaka yang dimiliki sehingga dapat membuat kota ini bisa bertahan tetap hidup, menghidupi, dan berkelanjutan dengan konsep living museum yang diterapkan pada Kawasan prioritas Kota Lama.
\end{abstract}

Kata Kunci : kota pusaka, living museum, kawasan prioritas

\section{PENDAHULUAN}

Berdasarkan UU No. 26 Tahun 2007 tentang Penataan Ruang yang berisi perlunya pengembangan kawasan yang memiliki fungsi pelestarian warisan budaya lokal dalam bentuk kawasan strategis maupun bentuk kawasan perdesaan serta UU No. 11 Tahun 2010 tentang Cagar Budaya telah mengamanatkan pelestarian cagar budaya pada dimensi darat dan air melalui pelindungan, pengembangan, dan pemanfaatan cagar budaya; dan PP No. 15 Tahun 2010 tentang Penyelenggaraan Penataan Ruang mengamanatkan pengembangan kawasan strategis dari sudut kepentingan sosial dan budaya yang mencakup berbagai kawasan peninggalan budaya maupun yang memberikan fungsi peningkatan kualitas sosial dan budaya, maka Direktorat Jenderal Penataan Ruang Kementerian Pekerjaan
Umum telah menginisiasi pelaksanaan Program Penataan dan Pelestarian Kota Pusaka (P3KP) dapat berjalan secara efektif di berbagai Provinsi di Indonesia khususnya pada kota-kota yang tergabung dalam Jaringan Kota Budaya. Tujuan dari inisiasi ini adalah untuk mendorong pemerintah daerah dapat melaksanakan P3KP dan menyusun Rencana Aksi Kota Pusaka dalam rangka untuk melestarikan aset pusaka, meningkatkan kapasitas pengelolaan kota pusaka, dan meningkatkan kualitas ruang kota pusaka yang lebih berkelanjutan baik secara lingkungan, ekonomi dan sosial budaya.

Dalam rangka mendorong pelaksanaan Program Penataan dan Pelestarian Kota Pusaka (P3KP) agar target terwujudnya Jaringan Kota Pusaka Indonesia atau Indonesia Heritage City 
(IHC) dapat tercapai untuk 10 kota terpilih salah satunya yakni Kota Sawahlunto.

Perjalanan panjang sejarah Indonesia tidak lepas dari kependudukan kolonial. Berbagai kota di negeri ini menjadi saksi sejarah lahirnya Bangsa Indonesia. Sawahlunto adalah salah satu diantara sejumlah kota yang terletak di kawasan Bukit Barisan di Sumatera Barat, dengan riwayat sejarah sebagai kota yang dipandang sebelah mata hingga diintervensi oleh Belanda. Kota ini dijuluki sebagai Belanda kecil karena banyak terdapat bangunan-bangunan peninggalan Pemerintah Hindia Belanda yang sampai sekarang masih tegak berdiri. Terdapatnya bangunanbangunan berarsitektural negeri kincir angin ini, tak lain merupakan konsekuensi dari geliat aktivitas perekonomian Sawahlunto sendiri yang dulunya berbasis pada sektor pertambangan, yakni batu bara. Batu bara inilah yang mengangkat nilai Sawahlunto hingga menjadi buah bibir bangsabangsa di Eropa.

\section{SAWAHLUNTO, KEMARIN DAN ESOK HARI}

Sawahlunto kini hadir sebagai kota tua yang menawan dengan slogan kota tambang yang berbudaya. Meneropong ke kota ini, mengingatkan kembali sejarah kejayaan pertambangan emas hitam, batu bara yang di bangun oleh Belanda, dengan segala fasilitas pendukungnya yang kini menjadi aset pusaka kota berbukit ini. Berakar dari penemuan batu bara di Sawahlunto, kompeni menerapkan kerja paksa dan mendatangkan pekerja dari berbagai daerah. Hal ini berimbas beragamnya suku di Sawahlunto hingga berbagai kesenian unik, menyadur dari berbagai daerah asal.

Perkembangan kota Sawahlunto dan roda perekonomian seolah terhenti ketika ditinggalkan PT. Bukit Asam. Denyut kehidupan mulai kembang kempis dan Sawahlunto terancam menjadi kota mati. Namun kisah dan tinggalan sejarah terus mewarnai kota tua ini. Saat ini kota Sawahlunto kembali bergeliat untuk bangkit dan 'memanggil kembali' masa keemasannya. Setelah merunut rangkaian peristiwa yang terjadi di kota ini, sangatlah penting untuk menelusuri setiap jejak transformasi kota dalam bentuk dokumentasi inventarisasi aset pusaka, yang dipengaruhi oleh kisah di masa lalu sehingga menunjukan potensi Sawahlunto menjadi kota pusaka yang multi etnik dengan dukungan karakter kota bekas pertambangan yang kuat sehingga Sawahlunto bisa terus diingat dan tetap hidup berkembang dengan potensi yang dimilikinya.

\section{METODE}

Metode yang digunakan adalah deskriptif dan eksploratif, dengan memusatkan pada kajian sejarah, budaya dan konteks kebijakannya. Studi kasus akan dibatasi pada kawasan kota pusaka di seluruh kecamatan di Kota Sawahlunto. Metode pengumpulan data yang digunakan adalah survey lapangan, wawancara dengan narasumber di lokasi, studi pustaka dan telaah peraturan dan kebijakan atau dokumen perencanaan yang terkait. Metode analisis data menggunakan analisis kualitatif yang dilakukan saling menjalin dengan proses pengumpulan data.

\section{HASIL DAN PEMBAHASAN}

\section{Sejarah Perkembangan Kota (Morfologi Kota)}

Jika mencari informasi tentang sejarah Sawahlunto ada berbagai kisah yang bisa dipahami salah satunya yakni berasal dari dua suku kata yakni sawah dan lunto. 'Sawah' yang menunjukan daerah tersebut pada saat itu digunakan sebagai lahan pertanian (sawah) dan 'lunto' berasal dari bahasa minang, 'alun tau' yang berarti belum tahu. Kata ini sering diucapkan masyarakat sekitar daerah sawah tersebut, saat orang Kubang menanyakan nama sebuah pohon yang berdiri tegak juga berbunga banyak di daerah itu. Saking cepatnya 'alun tau' diucapkan, makin terdengar seperti 'lunto' dan masyarakat Kubang mengira nama pohon itu adalah lunto.

Pada masa itu, Belanda sama sekali tidak melirik Sawahlunto sebagai daerah yang bisa menguntungkan negerinya. Sawahlunto dilihat sebagai daerah terisolir serta tidak memiliki banyak penduduk sehingga tidak bisa menghasilkan pajak yang menguntungkan Belanda. Topografi kota yang berbentuk seperti wajan semakin membatasi daerah ini dengan 
daerah sekitarnya, membuatnya semakin tidak memiliki nilai ekonomi.

Hingga pada tahun 1858, saat De Groot, peneliti geologi Belanda meyakini ada endapan batubara di Batang Ombilin. Akhirnya pada tahun 1867, De Greve, peneliti setelah De Groot ditugaskan untuk menyelidiki secara pasti kabar tersebut. Pada awal 1868, De Greve dengan ekspedisi pertamanya berhasil menemukan lapisan batubara di daerah Ulu Air, tepi Batang Ombilin. Namun sayang saat melakukan ekspedisi lanjutan pada tahun 1872, De Greve terseret arus sungai dan meninggal. Langkah De Greve akhirnya dilanjutkan RDM Verbeek pada tahun 1875 dan ditemukan dengan lebih rinci indikasi 200 juta ton batu bara di Kawasan Sungai Durian, Lapangan Soegar -dekat pusat Kota Sawahlunto sekarang-, Tanah Hitam dan juga Perambahan.

Tahun 1880 menjadi tahun awal penambangan di tanah Sawahlunto tepatnya di Sungai Durian (Soengai Doerian). Hingga pada tahun 1887 wilayah ini telah berkembang menjadi permukiman pekerja tambang dan juga pegawai tambang hanya saja terpisah jauh untuk menunjukkan strata sosial. Strata sosial yang lebih tinggi (Belanda) terletak di wilayah Kota Lama Sawahlunto sekarang ini. Semakin berkembang menunjang kegiatan pertambangan di bagian utara.

Kegiatan eksploitasi pertambangan yang makin menggeliat mendorong Pemerintah Hindia Belanda untuk membangun jalur penyaluran batubara dari Sawahlunto ke Pelabuhan terdekat di Kota Padang. Kereta Api menjadi pilihan transportasinya. Pada tahun 1889 dimulailah pembangunan jalur kereta api dari Padang dan hingga tahun 1891 jalur kereta api telah mencapai Padang Panjang yang dilanjutkan ke Bukittinggi. Pembangunan jalur kereta api selanjutnya yaitu dari Padang Panjang ke Solok melewati pinggir Danau Singkarak, selesai di tahun 1892. Pada tahun yang sama jalur dari Solok diselesaikan, menuju ke Muaro Kalaban, melalui Silungkang. Penyelesaian ini juga bersamaan dengan selesainya jalur kereta api dari Kota Padang menuju Pelabuhan Emma Haven (Pelabuhan Teluk Bayur sekarang). Stasiun pelengkap pun dibangun di Silungkang dan Muaro Kalaban. Tahun ini juga menjadi tahun perdana produksi batubara di Sawahlunto.

Kegiatan eksploitasi pertambangan juga tentu menguras banyak sekali tenaga kerja, untuk kemudahan juga pertimbangan upah yang akan jauh lebih murah, pada tahun 1893 dikirimkan 1.500 orang narapidana dari Pulau Jawa yang diyakini tidak akan dengan mudah melarikan diri saat dipaksa bekerja, tidak seperti pekerja tambang yang diambil dari penjara di Muaro Padang yang dengan mudahnya melarikan diri karena sudah mengenal daerahnya dengan baik. Narapidana ini dikirimkan dengan kereta api menuju Muaro Kalaban dan ditempatkan di dua daerah penampungan yaitu di daerah Muaro Kalaban dan Tanah Lapang. Selain bekerja di tambang, mereka pun dipaksa untuk mengerjakan jalur kereta api dari Muaro Kalaban ke Sawahlunto daerah pertambangan. Bekerja dengan saling dirantai pada bagian kaki, kemudian pekerja paksa ini disebut dengan nama orang rantai.

Kehadiran orang rantai dari Pulau Jawa khususnya telah menambah kekayaan sosial dan budaya di tanah Sawahlunto hingga muncul kekerabatan tunggal sekapal dan Bahasa Tansi. Bahasa Tansi menjadi bahasa dari kelompok sosial terbawah di struktur kolonial Sawahlunto, dan uniknya bahasa campuran ini bukan berasal dari aktivitas perdagangan dan persinggahan di sekitar pelabuhan di pesisir melainkan kehidupan perburuhan di pedalaman. Bahasa Tansi sendiri terdengar seperti Bahasa Minang namun terdapat unsur Jawa dan unsur-unsur dari etnis lain.

Akhirnya pada tahun 1894, jalur kereta api pun sampai ke pusat kegiatan Kota Sawahlunto. Dengan sampainya jalur kereta api ini maka untuk membantu menggerakkan dan mempercepat proses pertambangan dibangunlah sebuah PLTU pertama di Kota Sawahlunto. Pada tahun 1898, sebuah lubang tambang baru dibuka di daerah Soegar (sekarang diberi nama Lubang Tambang Mbah Soero). Perang Aceh pun pecah dan tanpa pilihan Belanda mengambil 800 orang pekerja paksa untuk dilatih militer dan membantu peperangan. Tambang kekurangan pekerja dan diputuskan untuk mendatangkan pekerja kontrak 
dari Bangsa Cina (Singapura). Tahun 1900-an, kawasan Saringan dibangun dengan ketiga struktur besar bernama silo untuk kemudahan pemrosesan dan penyaringan batubara. Kawasan ini dibangun di sebelah barat lubang tambang baru.

Tahun 1904 hingga 1920 menjadi tahun pembangunan gedung-gedung penunjang baik untuk kebutuhan pertambangan juga kebutuhan para pegawai pertambangan. Jauh di selatan di daerah Silungkang dibangun sebuah pasar (1904). Kemudian Rumah Fak Sin Kek, rumah seorang berkebangsaan Cina (1906). Tahun 1910 dibangun Gedung "Gluck Auf" - Gedung pertemuan dan pesta orang Belanda (sekarang Gedung Pusat Kebudayaan), dan Kantor Koperasi Pertambanga. Tahun 1916 dibangun Ombilin Meinen- Kantor Utama Pertambangan (sekarang PT BA-UPO). tahun 1917 dibangun gedung pertunjukkan komedi. Tahun 1918 dibangun Gudang Ransoemdapur umum bagi pekerja tambang, Wisma Ombilin - tempat peristirahatan pegawai tambang dan juga Stasiun Sawahlunto, di daerah Silungkang juga dibangun sebuah jembatan untuk menghubungkan Pasar Silungkang dengan Stasiun Silungkang. Tahun 1920 dibangun gereja, susteran dan sekolah bagi anak-anak Bangsa Belanda. Tahun 1922-1925 dibangunlah sebuah penjara orang rantai agar para pekerja ini tidak mudah melarikan diri. Penjara ini terletak tepat di depan kawasan pertambangan yang ada di daerah Sungai Durian.

Kehidupan pertambangan berakhir saat kandungan batubara dirasa sudah tidak mencapai skala ekonomi yang mencukupi, sehingga perusahaan tambang kemudian tidak melanjutkan kegiatan pertambangan di kota Sawahlunto diiringi dengan kepergian Belanda dari tanah air. Saat ini banyak bekas-bekas galian tambang yang masih tersisa disertai dengan beberapa kegiatan pertambangan liar. Seiring dengan terhentinya kegiatan pertambangan, maka pada akhir tahun 1990an kegiatan kereta api dihentikan karena volume-nya yang berkurang. Hingga akhirnya luasan Sawahlunto bertambah dan kini sudah terbagi ke dalam 4 (empat) kecamatan yaitu, Kecamatan Talawi, Kecamatan Barangin,
Kecamatan Lembah Segar dan Kecamatan Silungkang.

\section{Kondisi Masa Kini Kota Sawahlunto}

Penduduk Kota Sawahlunto berasal dari multi etnis yang sebagian besar merupakan keturunan dari para pekerja tambang di masa lampau. Sebagian besar pekerja di dominasi oleh pegawai negeri, pedagang dan petani. Struktur bangunan dan sarana pendukung yang ada memanfaatkan infrastruktur yang dibangun sebelumnya dengan beberapa bangunan menyesuaikan dengan perkembangan gaya arsitektural yang saat ini ada di Indonesia.

Saat ini kantong-kantong perumahan tidak terbagi lagi dan cenderung menyebar sesuai dengan perkembangan kota. Bangunan-bangunan klasik bekas kegiatan tambang banyak yang diubah menjadi kegiatan wisata seperti museum, hotel, gedung pertemuan warga, dan lain sebagainya. Untuk perumahan warga, tersebar hingga keluar kota inti sampai batas wilayah kota Sawahlunto, terutama penduduk yang bekerja di sektor pertanian. Adanya kegiatan-kegiatan pariwisata juga memicu pola perumahan yang berbeda dan mendekati kawasan-kawasan wisata tersebut.

Sarana prasarana pendukung telah mengalami peningkatan kapasitas sesuai dengan perkembangan kota, seperti rencana rehabilitasi pembangunan Pasar Sawahlunto dan lain sebagainya Setelah kegiatan pertambangan selesai, kelompok-kelompok masyarakat terbagi menjadi kelompok-kelompok profesi atau wilayah. Saat ini relatif tidak terjadi pembagian kelas yang bersifat vertikal yang disertai hak-hak khusus sehingga hubungan antar kelompok ataupun antar individu relatif tidak ada kesenjangan yang signifikan seperti pada masa orang rantai dulu. Hubungan yang terjadi bersifat fungsional dan sesuai kepentingan masing-masing individu yang di sesuaikan dengan profesi atau wilayah geografisnya.

Jaringan telekomunikasi dan listrik berkembang seiring dengan perkembangan jaman yang berperan besar dalam meningkatkan fungsi perkotaan pusat kota Sawahlunto saat ini terdiri 
dari bagian kota tua Sawahlunto dan pusat Pemerintahan. Dari lokasi, tidak terjadi perubahan lokasi dari pusat kota Sawahlunto. Perkembangan kota menyebabkan berubahnya fungsi serta pola interaksi penduduk yang tinggal di pusat kota. Fungsi manajemen perusahaan bergeser menjadi fungsi manajemen pemerintahan Kota Sawahlunto. Pusat kota yang awalnya hanya diperuntukkan untuk orang Belanda dan Pegawai yang notabene merupakan warga kelas satu, saat ini dapat ditempati secara tanpa ada segregasi sosial berdasarkan ras dan kelas ekonomi.

Kegiatan yang berkembang selain fungsi pemerintahan adalah kegiatan pariwisata yang memanfaatkan banyaknya bangunan-bangunan kuno bekas kantor tambang yang dimanfaatkan sebagai museum dan hotel. Bagian permukiman ini didominasi oleh kegiatan pertanian/perkebunan yang dilakukan oleh Masyarakat. perkembangan kegiatan ini salah satunya disebabkan oleh Kebijakan Pemerintah Kota Sawahlunto yang mendorong kegiatan pertanian/perkebunan oleh masyarakat melalui pemberian bibit gratis, pembangunan jalan produksi dan lain sebagainya. Dari data RTRW terakhir, menunjukkan kegiatan perkebunan campuran mengambil porsi hingga 35 \% dari Kota Sawahlunto. Rel Kereta Api dan Stasiun Kereta Api pada awalnya mendukung fungsi distribusi barang dan orang di Sawahlunto. Pada saat kegiatan tambang dihentikan, maka otomatis jaringan Kereta Api tidak berfungsi sebagaimana dirancang di awal yaitu simpul transportasi kota Sawahlunto. Saat ini kereta Api dan Stasiun KA berubah fungsinya menjadi kegiatan pariwisata. Jaringan jalan internal dan eksternal di banyak dipengaruhi oleh letak dan posisi kota Sawahlunto yang berada di Jalur Lintas Sumatra.

Transformasi fungsi pertambangan menjadi pariwisata tidak terlalu signifikan mempengaruhi pola jaringan jalan. Saat ini banyak terjadi perubahan fungsi kekhususan dari bagian kota. Perumahan pekerja tambang tidak menjadi bagian khusus seiring dengan tidak adanya konsep segregasi sosial pada masa sekarang. Bagian kota yang dianggap khusus adalah kegiatan-kegiatan yang diperuntukkan untuk kegiatan pariwisata, seperti Museum Kereta Api, Museum Gudang Ransoem, Waterboom, Kebun Binatang dan lain sebagainya. Kekhususan ini terlihat dari fisik bangunan ataupun fungsi strategis dari bagian tersebut terhadap perekonomian Kota Sawahlunto. Dari sejarah singkat kota Sawahlunto, di atas kami mencoba melakukan inventarisasi awal dari aset-aset pusaka yang tersebar dari peninggalan di masa lampau baik pada masa kerajaan maupun pada masa penjajahan Belanda berdasarkan data sekunder yang kami dapatkan. Inventarisasi aset pusaka terbagi menjadi pusaka ragawi (tangible), pusaka tak ragawi (intangible), pusaka alam, dan pusaka saujana. Berdasarkan inventarisasai Balai Pelestarian Peninggalan Purbakala Batusangkar sampai dengan tahun 2011, cagar budaya tidak bergerak di Kota Sawahlunto berjumlah 74 (tujuh puluh empat) buah. Cagar budaya tersebut tersebar dalam 4 kecamatan yaitu:

a. Kecamatan Talawi dan Kecamatan Barangin sebagai wilayah bagian utara,

b. Kecamatan Lembah Segar sebagai wilayah bagian tengah dan

c. Kecamatan Silungkang sebagai wilayah bagian selatan.

Dalam Kebijakan dan Strategi perkotaan daerah 2012 - 2025 telah dijabarkan arah akan dikembangkannya wilayah- wilayah tersebut diatas yaitu:

1. Wilayah bagian utara, dengan topografi agak berbukit juga kawasan-kawasan datarnya lebih didominasi pertanian. Kegiatan baru juga mulai berkembang di wilayah ini, terutama pengembangan pariwisata alam dengan memanfaatkan lahan-lahan bekas pertambangan telah mendorong berkembangnya kawasan perumahan dan kegiatan pendukungnya. Pertanian rakyat di wilayah ini disamping persawahan tetapi juga telah berkembang budidaya tanaman coklat sebagai program utama pemerintah daerah dalam mendorong perekonomian rakyat. Sesuai dengan RTRW kota Sawahlunto wilayah ini akan menjadi pusat kegiatan wisata 
khususnya wisata alam, dan pusat perkantoran pemerintah.

2. Wilayah bagian tengah, dengan Kota Lamanya yang berdiri bangunan-bangunan penunjang kegiatan pertambangan pada abad 18 yang berarsitektur Belanda dan Cina, antara lain bangunan perkantoran, bangunan pertambangan dan perumahan pegawai, bangunan pusat budaya, bangunan koperasi dan penginapan, bangunan pengusaha Cina (Pek sing Kek), bangunan gereja dan sekolah kristen serta Stasiun Kereta Api. Pada saat ini bangunan-bangunan tersebut telah ditetapkan pemerintah daerah sebagai bangunan bersejarah (heritage).

3. Wilayah bagian selatan, dengan penduduk yang mempunyai keterampilan turun temurun dalam menenun kain, yang dikenal dengan tenun Silungkang.

\section{Isu Strategis Wilayah Kota Sawahlunto}

Terdapat beberapa isu strategis di Kota Sawahlunto, diantaranya :

1. Potensi terdapatnya bangunan-bangunan cagar budaya/heritage dan kebutuhan perlindungan kawasan cagar budaya/heritage dan pengembangan sebagai living musium

2. Kebutuhan Konservasi lingkungan menyangkut lahan bekas tambang, ketersedian air, daerah rawan longsor. Masalah lingkungan ini penting untuk menunjang daya dukung lingkungan dan keberlanjutan pembangunan.

3. Kebutuhan peningkatan Sumberdaya Manusia untuk pengembangan pariwisata dan penambangan

4. Permasalahan Kondisi Sanitasi, Air Minum, dan Jalan

Secara umum kondisi sarana dan prasarana kota seperti sanitasi, air minum, jalan kota baik, namun kuantitas dan kualitas fisiknya perlu ditingkatkan sebagai akibat dari kondisi ataupun tuntutan kebutuhan yang perlu dipenuhi serta manajemen pengelolaannya pun perlu dibenahi.

Diharapkan dengan kuantitas, kualitas dan pengelolaan yang betul-betul memenuhi standar sebagai suatu kota dengan memiliki konsep perencanaan berwawasan lingkungan dan berkelanjutan.

Setelah mencoba menelusuri kisah sejarah Kota Sawahlunto dan melakukan survey lapangan serta diskusi dengan masyarakat, penulis mencoba memetakan hasil inventarisasi aset pusaka yang ada di kota ini. Peninggalan arsitektur akan memberikan setting dari kisah masa lalu yang akan mudah diingat oleh generasi masa kini dan generasi yang akan datang. Kota Pusaka adalah kota yang memiliki kekentalan sejarah yang bernilai dan memiliki pusaka alam, budaya baik ragawi dan tak-ragawi serta rajutan berbagai pusaka tersebut secara utuh sebagai aset pusaka dalam wilayah/kota atau bagian dari wilayah/kota, yang hidup, berkembang, dan dikelola secara efektif.

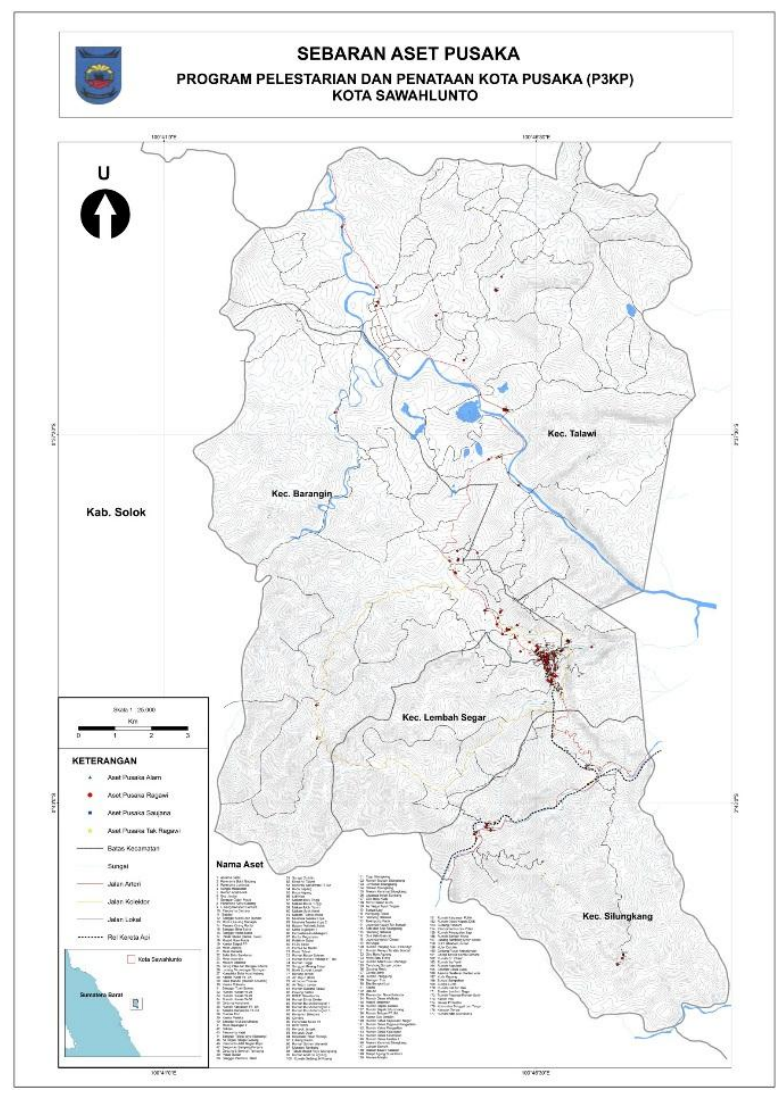

Gambar 1. Peta Sebaran Aset Pusaka di Kota Sawahlunto

Dari sebaran aset di atas, penulis mencoba membuat pengelompokkan aset sehingga dapat menjadi dasar alam pengembangan Kawasan per kelompoknya (cluster). 


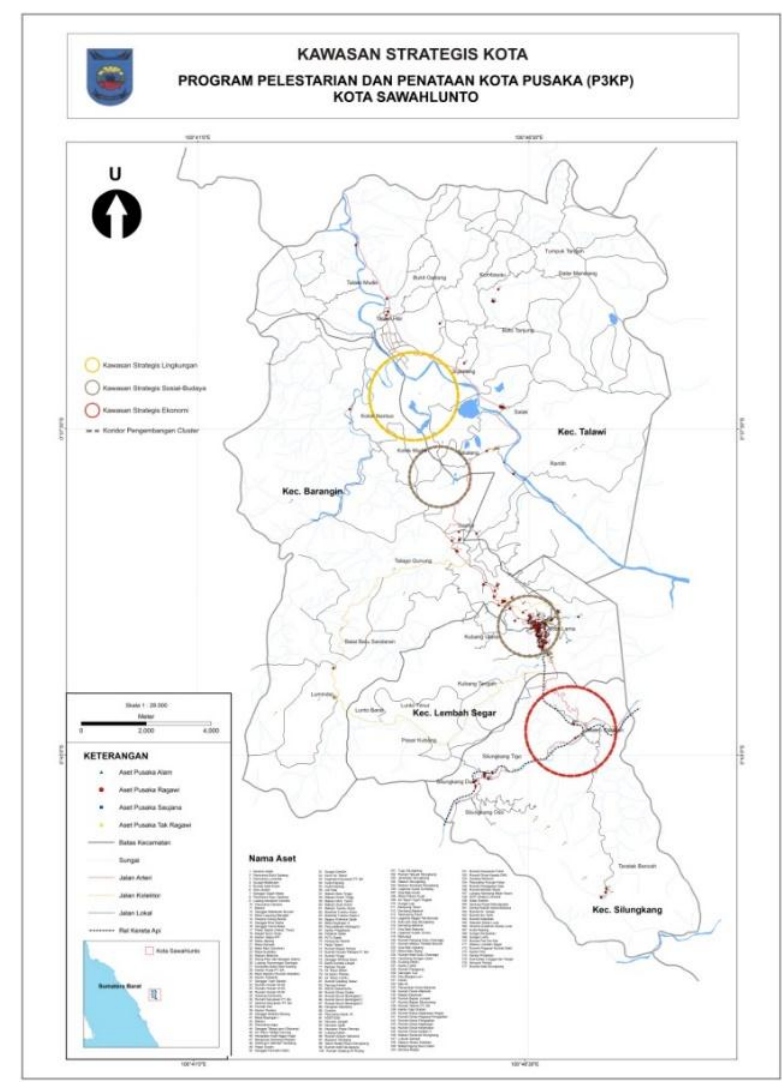

Gambar 2. Proses Clusterring berdasarkan kedekatan atau kemiripan objek

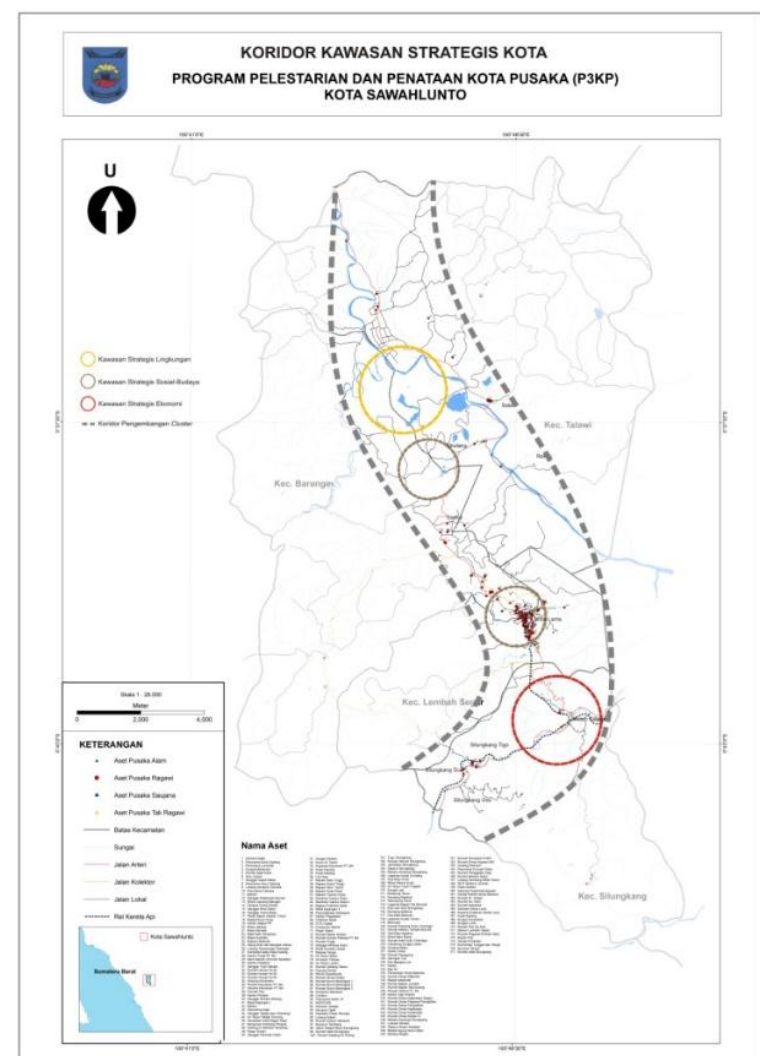

Gambar 3. Proses Clusterring berdasarkan kedekatan atau kemiripan objek

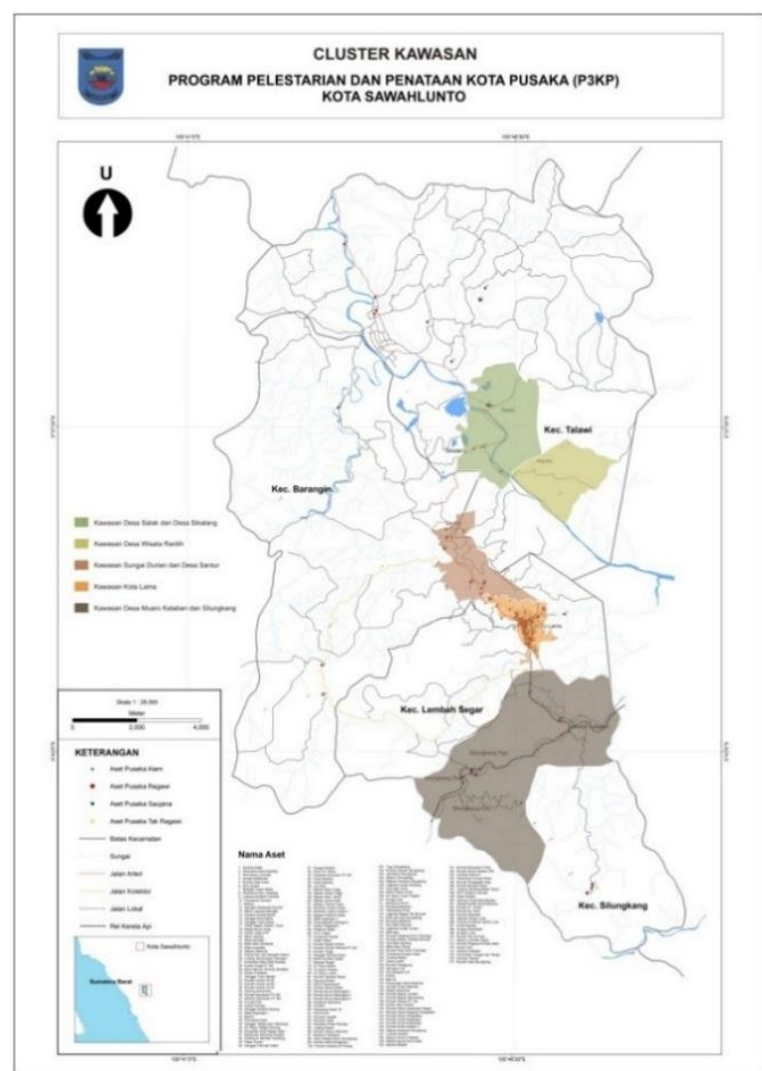

Gambar 4. Proses Clusterring berdasarkan kedekatan atau kemiripan objek

\section{Kondisi Aset Pusaka, Signifikansi Kota Pusaka dan Berbagai Permasalahannya}

1. Cluster 1 : Kawasan Muaro Kalaban dan Silungkang

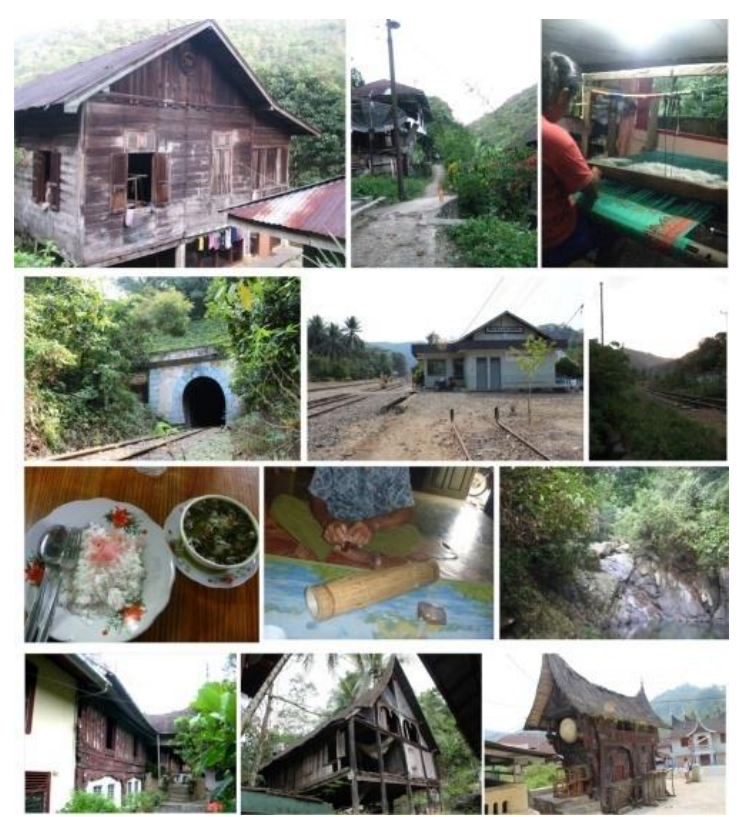

Gambar 5. Aset Pusaka di Kawasan Muaro Kalaban dan Silungkang 
Isu cluster ini :

a. Keberadaan rumah adat Silungkang yang mungkin terancam akibat status kepemilikan pribadi

b. Potensi wisata dari jalur kereta api dan stasiunnya yang terintegrasi dengan kerajinan tenun dan kuliner khas kaitannya dengan kawasan strategis ekonomi

c. Kegiatan menenun tidak bisa dilihat setiap waktu

d. Terdapat potensi nilai-nilai suku minang

2. Cluster 2 : Kawasan Kota Lama

Isu cluster ini :

a. Pertumbuhan kawasan yang mengancam tema pusaka "living museum"

b. Kualitas ruang yang berubah dari aslinya, wajah yang terliat tidak mewakili makna yang ingin disampaikan

c. Nyawa dari kegiatan pertambangan yang sudah tidak terlalu terasa

3. Cluster 3: Kawasan Durian dan Santur

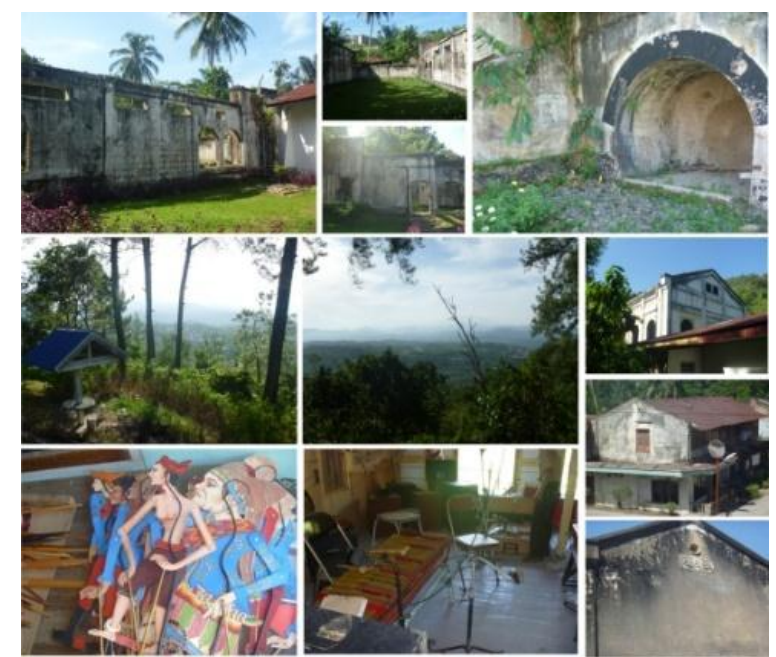

Gambar 6. Aset Pusaka di Kawasan Durian dan Santur

Isu cluster ini :

a. Aset tersebar di atas kawasan rawan bencana (rawan sesar dan longsor)

b. Kurangnya informasi yang menyatakan bahwa kawasan ini adalah lokasi penambangan pertama di Kota Sawahluntoyang mendorong pembangunan di Kota Lama serta sebagai tempat berkembangnya sosial budaya orang rantai

c. Memiliki potensi panorama alam

4. Cluster 4: Kawasan Desa Rantih
Isu cluster ini :

Potensi wisata alam yang belum memiliki penanda serta pihak yang siap sedia memandu dan memberikan informasi

\section{Cluster 5: Kawasan Desa Salak dan Sikalang}
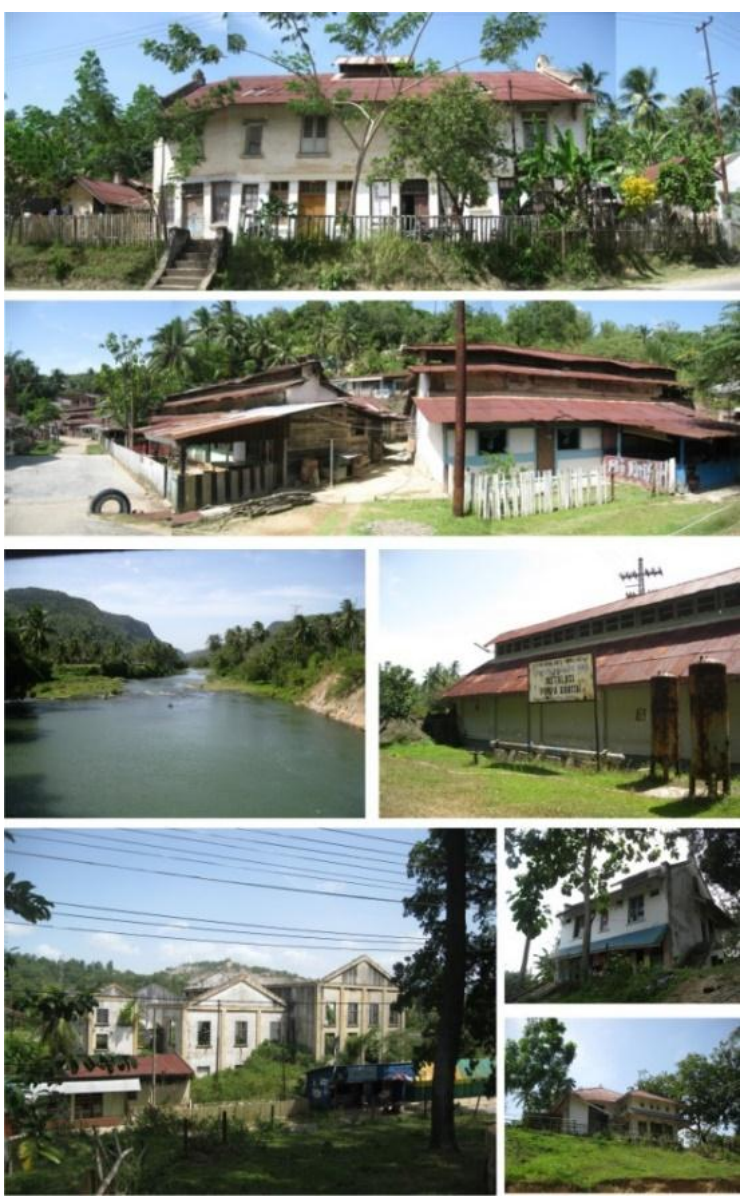

Gambar 7. Aset Pusaka di Kawasan Desa Salak dan Sikalang

Isu cluster ini :

a. Terdapat bagian dari runutan cerita kejayaan masa pertambangan kolonial yang tidak difungsikan lagi, jikapun masih difungsikan kondisinya kurang baik dan dikhawatirkan hilang (dibongkar/rusak). Hal ini terjadi karena letaknya yang jauh dari Kota Lama

b. Terdapat potensi serta ancaman melihat kedekatannya dengan kawasan yang direncanakan sebagai pusat pemerintahan (kolok-sikalang)

c. Potensi sosial budaya yakni sanggar dan seni tangsi belum muncul dan kurang terangkat

d. Terdapat potensi sumber bahan baku ekonomi kreatif (batu bara). 


\section{Profil Kawasan Prioritas}

Tata Kota Sawahlunto sebagai sebuah kota tambang telah dirancang sedemikian rupa oleh Belanda. Meskipun Sawahlunto merupakan kota tambang kecil, namun memiliki fasilitas tambang yang sangat lengkap. Mulai dari lubang tambang, pabrik pengolahan, jalur kereta api, dan kantor Perusahaan Pertambangan. Belanda membagi kota tua Sawahlunto ini menjadi lima kawasan, yaitu Kawasan industri perusahaan tambang, kawasan komersial, kawasan permukiman tambang, kawasan administrasi pemerintahan, dan kawasan rumah sakit. Semua itu masih tertata dengan baik dan masih bertahan hingga saat ini.

Kota Sawahlunto merupakan sebuah kota yang keberadaannya tidak dapat dilepaskan dari aktivitas pertambangan yang masih berlanjut hingga saat ini. Pada masa lalu, aktivitas pertambangan dijalankan dengan mempekerjakan para buruh tambang atau orang rantai, yang didatangkan dari beberapa daerah di Indonesia. Sistem perbudakan dengan berbagai peristiwa tragis yang mengikutinya menjadikan sebuah peristiwa sejarah gelap warga Kota Sawahlunto. Bekas-bekas aktivitas perbudakan dan tradisi yang ditinggalkan oleh para orang rantai masih ditemukan sampai saat ini, dan menjadikan satusatunya tradisi orang rantai yang ada di dunia.

Berikut dipaparkan proses penentuan deliniasi kawasan prioritas yang juga melibatkan pihak Kota Sawahlunto. Proses penentuan ini melalui beberapa tahap sebagai berikut:

1. Dalam RTRW Kota Sawahlunto 2012-2032 disebutkan, kawasan strategis yang berkaitan dengan aspek sosial budaya khususnya identitas kota adalah kawasan Kota Lama (Kecamatan Lembah Segar).

2. Mengacu pada rapat koordinasi kegiatan inventarisasi Kota Pusaka Kota Sawahlunto (Rabu, 19 Juni 2013), kawasan Kota Lama-lah yang memiliki potensi untuk dijadikan sebagai kawasan prioritas. Dengan catatan memperluas batas-batas yang telah ada sebelumnya, mengingat batas luasan yang telah ditentukan oleh Dinas Pekerjaan Umum Jakarta untuk kawasan prioritas adalah 200 hektar. Memaksimalkannya dengan memasukkan beberapa titik saujana yang ada menjadi salah satu bahasan yang didiskusikan.

3. Mengacu pada rapat koordinasi kegiatan inventarisasi Kota Pusaka Kota Sawahlunto (Rabu, 19 Juni 2013), walaupun kawasan Kota Lama telah masuk dalam rencana kawasan strategis namun masih banyak yang belum dilengkapi implementasi fisik lapangannya. Peserta juga menilai masih banyak hal yang bisa digali dari potensi yang dimiliki kota lama ini. Meskipun ada kecamatan atau kawasan lain yang juga berpotensi, namun melanjutkan apa yang sudah dimulai menjadi pertimbangan yang cukup untuk menjadikan kawasan Kota Lama sebagai kawasan prioritas.

4. Survey lapangan dan hasil pemetaan memperlihatkan konsentrasi aset pusaka yang memiliki ciri khas dan menunjukan identitas masa lalu juga masa kini pada Kota Lama Sawahlunto. Hal ini juga membuktikan alasan pemilihan kawasan Kota Lama sebagai kawasan strategis bernilai sosial dan budaya di Kota Sawahlunto.

5. Sepakat untuk menjadikan kawasan Kota Lama sebagai kawasan prioritas dengan menambah luasan termasuk memasukkan 2 (dua) aset pusaka saujana yaitu, Puncak Polan yang berada di Kecamatan Lembah Segar dan Panorama Cemara yang berada di Kecamatan Barangin. Juga Lubuk Sampik sebagai aset pusaka alam yang masih alami. Sehingga kini kawasan prioritas Kota Sawahlunto mencakup 2 (dua) buah kecamatan yang dibatasi oleh sungai (Batang Sumpahan dan pertemuan arus Batang Lunto dari selatan dengan Batang Sumpahan dari barat).

6. Penentuan delineasi menggunakan jalan (jalan kolektor, jalan lokal, jalan setapak), sungai dan juga kontur.

7. Tanggal 22 Juli 2013, Peta Deliniasi yang telah dibuat dikirim kepada pihak kota untuk diinformasikan juga didiskusikan dengan jajaran terkait program kota pusaka, terutama kawasan terpilih prioritas 
8. Dari hasil rapat koordinasi yang diselenggarakan oleh kota (Senin, 19 Agustus 2013) dengan jajarannya (PU, BAPPEDA, Pariwisata, dan juga Camat, Kades juga Lurah setempat) didapatkan penyesuaian batas delineasi dan juga tambahan beberapa asset pusaka. Dengan berbagai pertimbangan didapatkan batas delineasi akhir yang tercantum pada poin selanjutnya.

9. Keterangan batas :

- Sebelah Utara :

dibatasi dengan jalan yang menuju ke Panorama Cemara terus ke arah timur menuju jalan tembus ke arah Puncak Polan.

- Sebelah Timur :

dari jalan tembus ke arah Puncak Polan lalu turun lembah ke arah selatan menuju jalan lokal permukiman.

- Sebelah Selatan :

dari jalan lokal permukiman lalu ke bawah lagi menuju jalan setapak ke arah sungai kecil yang mengarah ke Lubuk Sampik. Ditambah Lubang Kalam yang panjangnya hingga 875 meter. Dari jalan setapak Lubuk Sampik, arah barat ke atas.

- Sebelah Barat :

dari jalan setapak Lubuk Sampik ke arah atas diambil batas dengan kontur yang bersambung ke jalan kolektor yaitu $\mathrm{Jl}$. Soekarno Hatta yang jika dilanjutkan bertemu dengan jalan menuju Panorama Cemara.

Penggambaran Deliniasi Kawasan Prioritas Kota Sawahlunto. Luas total 193,60 hektar. (Peta Deliniasi terlampir pada halaman selanjutnya)

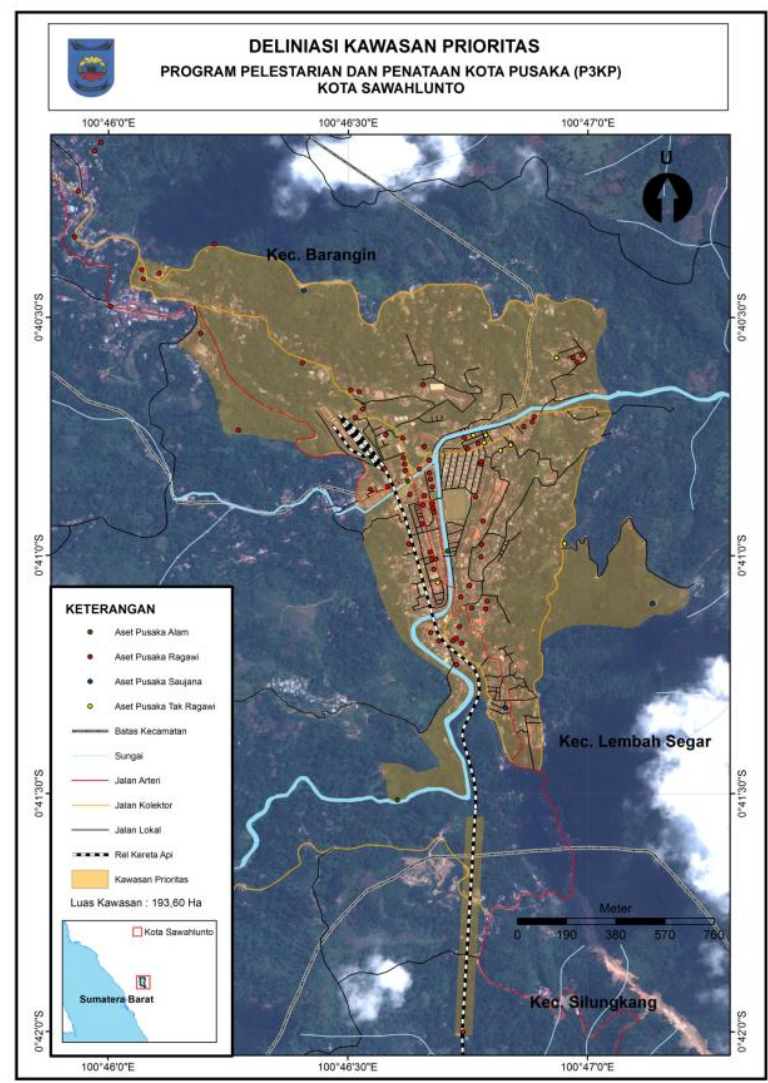

Gambar 8. Peta Delineasi Kawasan Prioritas (Kota Lama Sawahlunto)

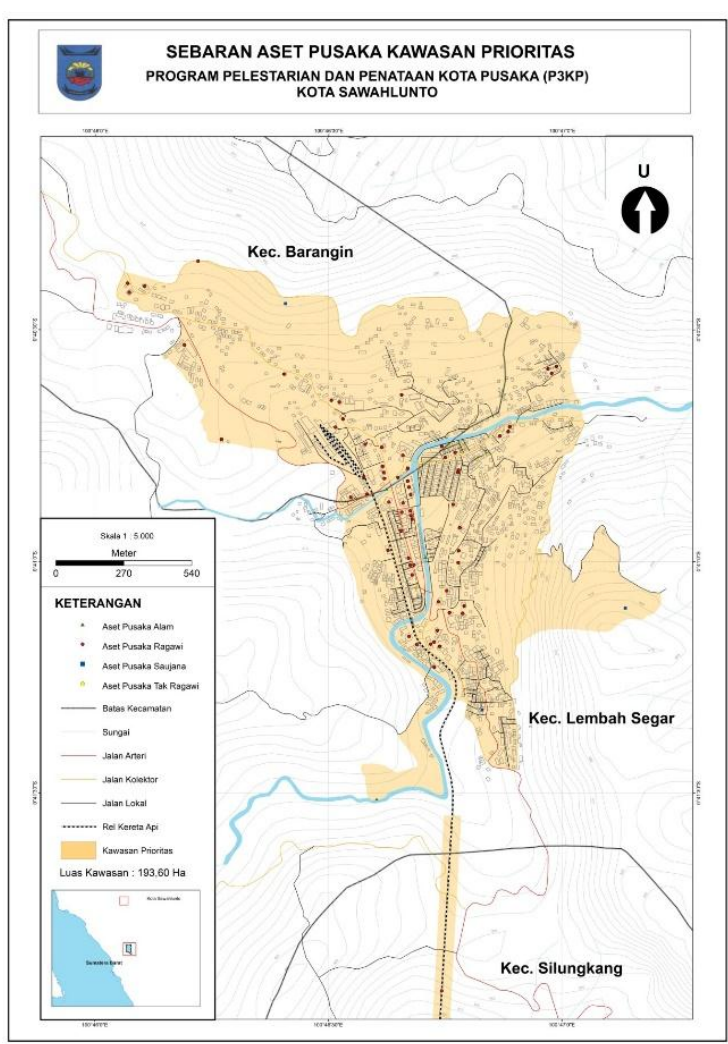

Gambar 9. Peta Sebaran Aset Pusaka di Kawasan Prioritas (Kota Lama Sawahlunto) 


\section{Usulan Konsep Strategi Pengembangan Kawasan Prioritas}

Sawahlunto as a LIVING MUSEUM

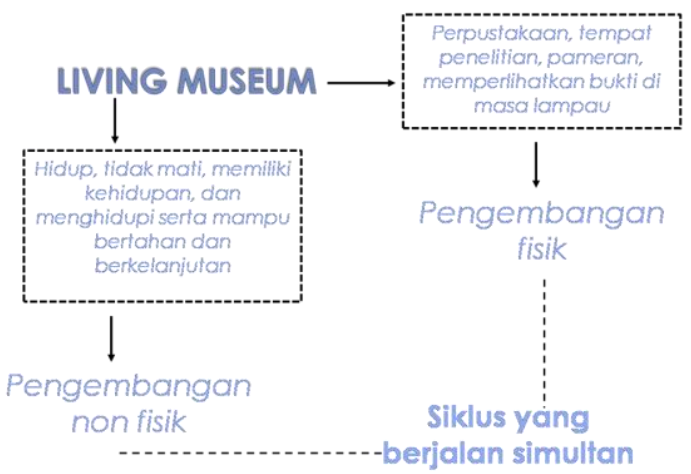

Gambar 10. Usulan Konsep Strategi di Kawasan

Prioritas (Kota Lama Sawahlunto)

Sawahlunto dihadirkan sebagai sebuah living museum atau museum yang hidup. Museum pada konteks ini adalah tempat untuk memamerkan atau memperlihatkan bukti-bukti kisah masa lampau yang ada di Kota Sawahlunto ini.tempat tersebut dapat berbentuk perpustakaan, tempat penelitian, galeri, dan sebagainya yang pengembangannya lebih ke arah fisik. Sementara 'hidup' pada konsep ini dimaknai sebagai sesuatu yang tidak mati, memiliki kehidupan dan menghidupi, serta mampu bertahan dan berkelanjutan sehingga membutuhkan pengembangan ke arah non fisik (aktivitas). Kedua arah pengembangan yang telah dijelaskan di atas diharapkan dapat menjadi siklus yang berjalan secara simultan dan terus-menerus.

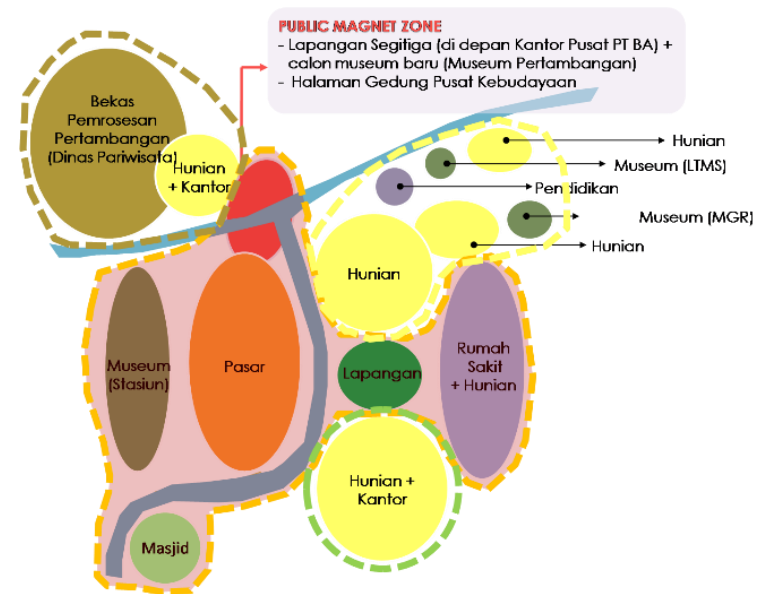

Gambar 11. Usulan Program Ruang di Kawasan Prioritas (Kota Lama Sawahlunto)
Program ruang yang digambarkan dari diagram bubble di atas mencoba memberikan usulan pengembangan zonasi yang akan digunakan nanti dalam penataan kawasan prioritas kota pusaka Sawahlunto ini.

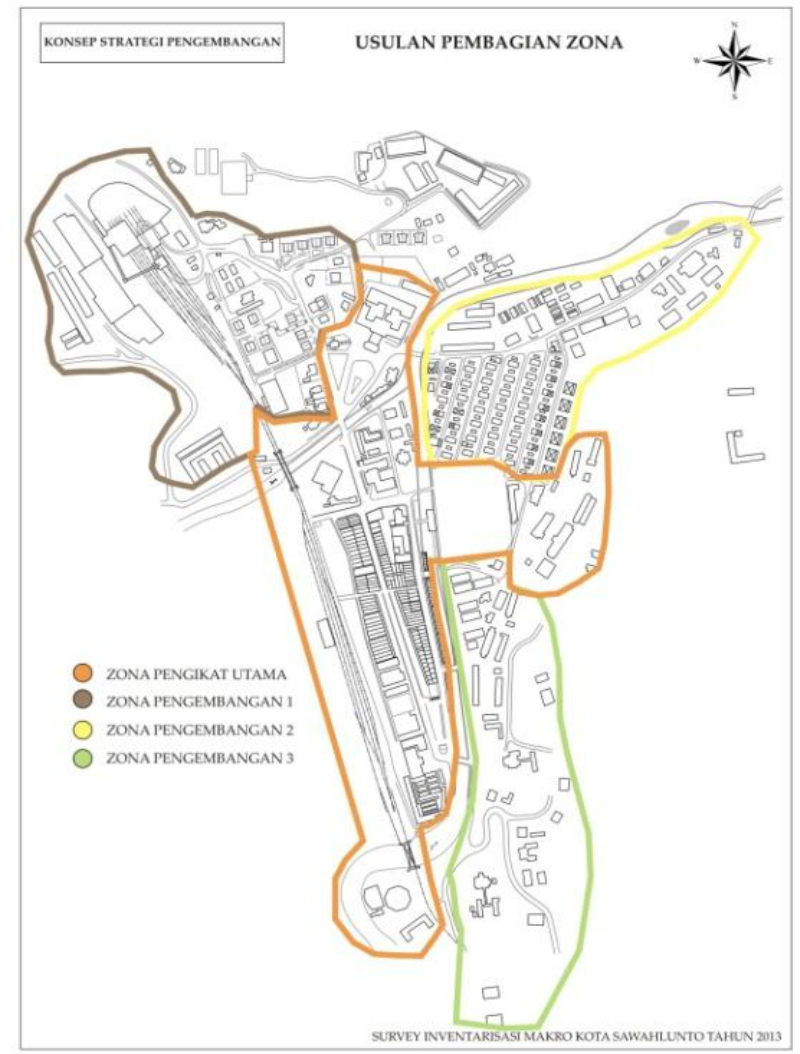

Gambar 12. Usulan Pembagian Zona di Kawasan Prioritas (Kota Lama Sawahlunto)

Kawasan prioritas ini akan dibagi menjadi 4 zona yakni, antara lain:

1. Zona pengikat utama yakni museum (stasiun), pasar, masjid, lapangan, dan rumah sakit dan hunian dan lapangan segitiga yang disiapkan sebagai public magnet zone..

2. Zona Pengembangan 1 yakni bekas-bekas proses kisah pertambangan dan hunian serta kantor

3. Zona Pengembangan 2 yakni hunian, Kawasan Pendidikan, dan museum

4. Zona Pengembangan 3 yakni hunian dan kantor yang selanjutnya akan berkembang karena diprediksi akan meningkatnya jumlah penduduk (pendatang) di Sawahlunto. 


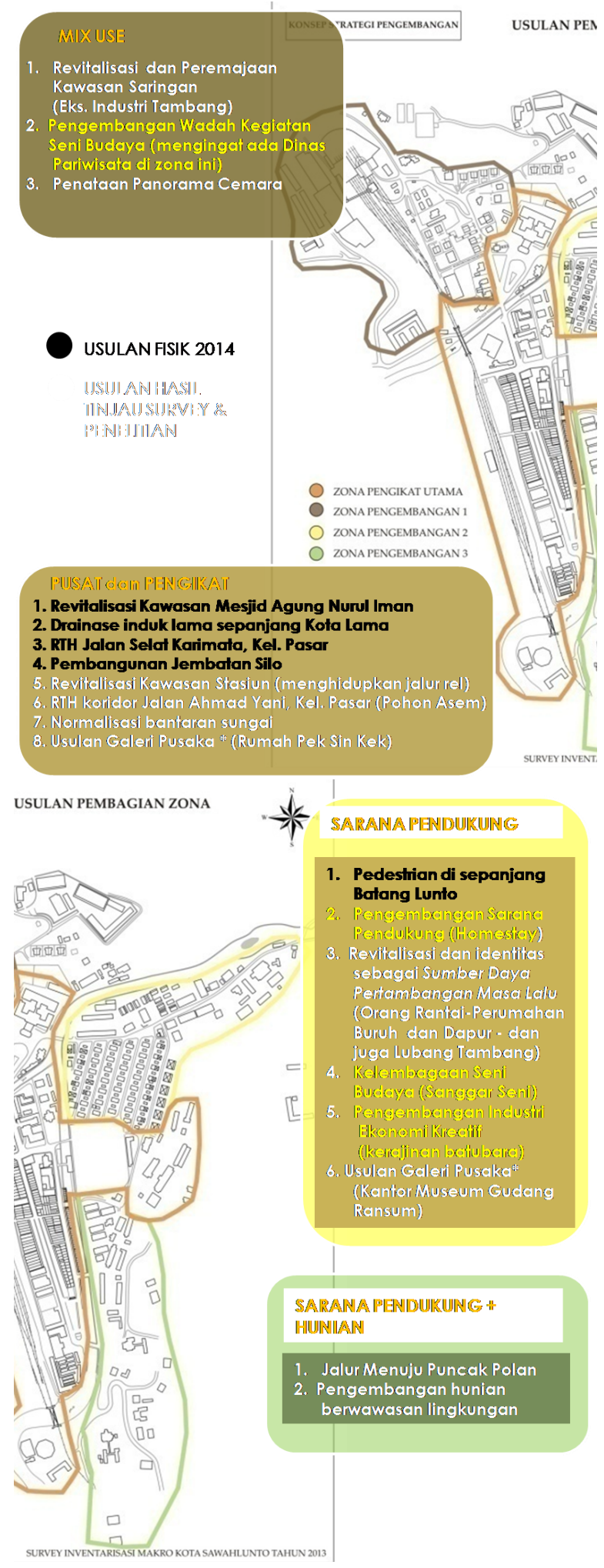

Gambar 13. Usulan Program Penataan Kawasan Prioritas (Kota Lama Sawahlunto)

\section{SIMPULAN}

Kota Sawahlunto di Provinsi Sumatera Barat merupakan salah satu kota yang tergabung dalam Jaringan Kota Pusaka Indonesia (JKPI) dalam P3KP (Program Penataan dan Pelestarian Kota Pusaka) bertujuan untuk mempertahankan aset pusaka. Aset pusaka Kota Sawahlunto tidak terlepas dari sejarah dan kejayaan kota ini pada masa lalu khususnya pada masa penjajahan Belanda. Penelitian ini bertujuan mengidentifikasi ragam pusaka dan merumuskan strategi pelestarian Kota Pusaka Sawahlunto. Metode yang digunakan adalah kualitatif deskriptif dan ekslporatif dengan kajian sejarah, budaya dan kebijakan. Data dikumpulkan dengan survei lapangan, studi literatur dan wawancara. Hasil penelitian diperoleh struktur Kota Sawahlunto dikembangkan berdasarkan potensi aset pusaka yang dimiliki sehingga dapat membuat kota ini bisa bertahan tetap hidup, menghidupi, dan berkelanjutan dengan konsep living museum yang diterapkan pada Kawasan prioritas Kota Lama.

\section{DAFTAR PUSTAKA}

Asoka, Andi,dkk. 2005. Sawahlunto: Dulu, Kini, dan Esok. Padang: Pusat Studi Humaniora Universitas Andalas.

BPPI dan Kementerian PU. 2012. Modul Perencanaan Penataan dan Pelestarian Kota Pusaka. Jakarta: Kementerian PU Republik Indonesia.

Dewantara, Made Handijaya. 2013. Wisata Industri Pertambangan Masa Lampau di Sawahlunto, Sumatera Barat.

Dinas Pariwisata dan Kebudayaan Kota Sawahlunto. 2012. Nomination Dossier Historical Coal Mining Town of Sawahlunto. Sawahlunto: Pemerintah Kota Sawahlunto.

Herwandi. 2007. Sawahlunto dan Malaka : Kerjasama Kota "Kembar" dalam Bidang Pengelolaan Sumberdaya Budaya. Makalah dipresentasikan dalam Seminar Internasional "50 tahun Merdeka: Hubungan Indonesia Malaysia", di University Malaya, Kualalumpur, 17-21 Juli 2007. 
Kantor Peninggalan Bersejarah dan Permuseuman Kota Sawahlunto. 2013a. Guidelines

Bangunan dan Perkotaan Sawahlunto. Sawahlunto: Pemerintah Kota Sawahlunto.

Tim Kota Pusaka Sawahlunto. 2013b. Reinventarisasi dan Pemutakhiran Database Cagar Budaya Kota Sawahlunto. Sawahlunto: Pemerintah Kota Sawahlunto.

Kementerian Koordinator Kesejahteraan Rakyat. 2013. Pedoman Umum PNPM Pusaka. Jakarta: Badan Pelestarian Pusaka Indonesia.

Martokusumo, Widjaja. 2008. Mendaur Ulang Kota Tambang Sawahlunto: Beberapa Catatan tentang Pendekatan Konservasi dalam Revitalisasi. Makalah dengan tema kajian Revitalisasi Kota Tambang Sawahlunto.

Pemerintah Kota Sawahlunto. 2001a. Sawahlunto 2020: Agenda Mewujudkan Kota Wisata Tambang yang Berbudaya. Bandung: Pemerintah Kota Sawahlunto.

Peraturan Daerah Kota Sawahlunto Nomor 2 Tahun 2001 tentang Visi dan Misi Kota Sawahlunto Menuju Kota Wisata Tambang yang Berbudaya.

Peraturan Daerah Kota Sawahlunto Nomor 6 Tahun 2007 tentang Pengelolaan Benda Cagar Budaya.

Peraturan Daerah Kota Sawahlunto Nomor 2 Tahun 2010 tentang Penataan Kawasan Kota Lama.

Peraturan Pemerintah Nomor 10 Tahun 1993 tentang Pelaksanaan UU Nomor 5 Tahun 1992 tentang Bangunan Cagar Budaya.

Piagam Pelestarian Pusaka Indonesia Tahun 2003. 